同大病院・放射線部 前田繁信, 白川秀紀

愛知県総合保健センター 村上知枝美, 岩政裕昭

【目的】第56回総会にて，アンケート調査による大学病院における乳 房X線検査受診患者の心理状態について報告した。今回は，大学病 院と保健センターとでアンケート調査し，施設間による患者心理状 態の相違点について検討したので報告する。

【方法】調査によるデー夕収集は, 検査終了後患者に直接アンケート 用紙を配布し，回答を記入してもらう自記式(質問紙法)で行った。 調查期間は, 1999年 8 月 4 日 11月30日, 調査対象者は, 乳房X線 検査を受けるすべての患者とした，得られたデータの分析は，各質 問ごとに乳房検査経験の有無別に分類し，統計処理を行った．

【結果】技師による検查前の説明や圧迫の必要性に対する患者の理解 度において，施設間の差は認められなかった。しかし，検査結果に 対する不安やX線被曝に対する意識に施設間の差が認められた。大 学病院では約 $50 \%$, 保健センターでは約 $35 \%$ の患者が検査結果に対 する不安を抱いており, 大学病院では乳房疾患罹患者が乳房検査を 受搒するため，この傾向が著しく認められた．X線被曝に対する関 心度は, 保健センターでは, 受診経験による差は認められなかった が, 大学病院では, 経験者の方が関心は高かった。

164 注腸X線撮影法におけるルーチン・デクビタス撮影の画像評 価と考察

聖マリアンナ医大横浜市西部病院·画像診断部 岩瀬雅則, 白田研誠 立石貴代子，辻村栄美，大城和巳

【目的】当院の注腸X線検査では，透視撮影終了直後に左右デクビタ 又撮影を行っているが，その透視撮影は医師から技師に移行すると ともに近年検査精度の向上が求められ，撮影手技も変化してきた。 そこで撮影されたフィルムを画像評価, 分析·検討し, 注腸検査の 方向性を考察したので報告する.

【方法】4 年前と現在のルーチン手技の比較㧍よび透視撮影・デクビ夕 ス撮影のフィルムを画像評価基準フイルムを用い, 部位別, 評価項 目別(描出範囲, バリウム付着, FNP描出, 便残さ, ひび割れ等), 体位別(背·腹臥位，立位，左·右デクビタス)に評価を行い，補足評 価(影響因子の考察)も加え, 検査の実態と共に撮影体位ごとに分析. 検討した.

【結果】バリウムをほぼ全量移動させ大腸を二重造影像として背側・腹 側多方向で撮影する手法へ移行し, 粘膜描出回数および評価点の向 上がみられた。バリウム付着不良ケースでは粘膜の詳細な描出がで きず薄層像等の併用により描出評価は良好となった。立位およびデ クビタスでは上方となる腸管の描出は良好で残さも目立たなくなる が，バリウム付着は臥位に比べやや低評価. 下方腸管では腸管の重 なりや収縮・バリウム貯留等による描出不良が多かった。検查の後 半ほど徑縮・ひび割れ等が起こりデクビタス像への影響が多かっ た.

【考察】臥位を中心とした透視撮影で大腸各部の良好な粘膜描出像が 得られることにより，立位㧍よびデクビタス撮影の有用性は低くな り, 状況に応じた撮影で十分と考えられた。今回, その有用と考え られた状況を整理し, さらに撮影手技のパターン化が必要と考え た。

165 ルーチン注腸造影検査における虫垂病変拾い上げの試み 聖隷三方原病院・画像診断部廣瀬 愛, 松岡千秋, 永友秀樹 斎藤隆次，伊代田和孝，渱田一十

【目的】従来ルーチン注腸検査において虫垂描出の有無は, 所見とし てとらえられていない。しかし, 多くの虫垂病変の症例報告で, 注 腸造影における虫垂の無描出, 虫垂開口部の形態変化が指摘されて いる，そこで，われわれは，虫垂描出の有無と虫垂開口部の形態に 着目し病変を拾い上げられないかと考え, その精度について検討し
た。

【方法】1)平成 9 年 1 月 1 日〜平成12年 3 月 31 日の間に注腸検查を受 けた患者を対象に虫垂切除の既往を確認し, 無既往例の虫垂描出率 および無描出例の病変発見率を検討した．2）無虫垂切除例で虫垂無 描出であった症例を対象に虫垂開口部の形態を retrospectiveに検討し た.

【結果】1)虫垂切除無既往例の虫垂無描出率は約14\%, 虫垂無描出例 の病変発見率は，約1.3\%であった．2)約13\%に虫垂開口部の形態変 化を認めた。

【考察】虫垂切除の既往を確認したうえで，虫垂描出の有無と開口部 の形態に着目することにより病変の拾い上げが可能であると考えら れた。

\section{6 回転DRを用いた消化管3D画像の検討}

公立学校共済組合関東中央病院 - 放射線科 小林幸男，新井山充宏 坂井香澄, 時岡敦夫, 松崎宗弘, 細田 誠, 森崎真直

【目的】最近の血管撮影装置で用いられている回転DSA(DA)は，回転 方向からの観察だけでなくワークステーションを用いた3D画像処理 によって任意の方向からの観察が可能となり，頭部血管領域を中心 にその立体構造の把握に有用な手段となっている．われわれは，こ の撮影技術が対象としている部位のボリュームデータを得ていると いう点に注目し，管腔臓器への応用を考えた．今回，マーゲンファ ントムを用いて回転DRによる3D画像の描出を造影剤とその濃度に ついて検討したので報告する。

【方法】検討は二重造影像および充満像について行った。二重造影像 として，バリウム $180 \%$ およびその 10 倍希釈，20倍希釈で $100 \mathrm{ml} ， カ ゙$ ストログラフィン $100 \mathrm{ml}$ および $10 ， 30,50 \mathrm{ml}$ 水で希釈して総量 $100 \mathrm{ml}$ として撮影を行った。充満像として，ガストログラフィン $10 ， 30,50,100 \mathrm{ml}$ 水で希釈して総量 $300 \mathrm{ml}$ として撮影を行った. 得られたデータはワークステーションに送り3D画像を作成した。な お撮影は收集モードを $1.5^{\circ} / \mathrm{F} ， 2.5^{\circ} / \mathrm{F} ， 4^{\circ} / \mathrm{F}$ とてそれぞれ $14 ， 8 ， 5$ 秒スキャンで行った。

【結果】造影剤の濃度は高いほど付着性はよかったが，同時に3D画像 ではアーチファクトとして現れた。また，胃の解剖学的な構造のた めに撮影条件によってはハレーションが起こり，3D画像処理ができ ないことがあった．以上より，血管撮影装置を用いた回転DRによる 消化管3D画像の有用性および問題点について検討した。

\section{I.I.DR画像に扔ける画素值別周波数強調について} 昭和大学病院・放射線部 斉藤 肇，岩井譜憲，伊藤真紀子 武 俊夫，加藤京一，中澤靖夫

【目的】 DR画像の周波数処理は, 画素值に関係なく一様に同一の周 波数強調をしている，そのため周波数強調を必要としない領域にも 周波数強調をするため画質の低下を来す場合がある、今回，当院に 導入されたDR装置DR-2000Xは，画素值別に周波数強調度を変化さ せ，単一画像で複数の周波数強調が可能である。この処理機能を使 用し，画素值別に周波数強調度を变化させ，画質の改善を検討した ので報告する。

【方法】1)自作ファントムを作成し，画素值と周波数強調の関係につ いて検討した．2)臨床画像への適応について検討した。

【結果】1) 画素值別に周波数強調度を変化させることで画質への影響 が把握できた，2)画素值別周波数強調は，診断に有用であった。し かし, 目的部位の画素值と目的としない部位の画素值が同じ場合, 双方とも周波数強調をするため注意が必要であった.

168 DRによる気管支造影法の基礎的検討 山梨医科大学医学部附属病院・放射線部 池長 聰, 坂本 肇 新井誉夫, 秋山三郎, 佐野芳知 